\title{
Waste Management and Control Problems in Sokoto Metropolis: Projected Mitigation on the Syndrome
}

\author{
By Yusuf Alapata Ahmed ${ }^{*}$, Nathaniel Bayode Eniolorunda ${ }^{+}$, \\ Yakubu Fakai Musa ${ }^{ \pm}$\& Samuel Igra
}

This study assessed the nature of solid waste generation, its spatio-temporal pattern and existing management strategies in Sokoto metropolis. The greatest challenges facing cities in the developing world are; paucity of solid waste management and control. In the Nigeria context, solid waste management is characterized by inefficient collection, insufficient coverage of the collection system and improper disposal methods. In Sokoto metropolis, increase in population has resulted into accelerated of solid waste generation with pollution of all categories, and the consequent is dearth of modern management. The study used; selection of different wastes for observation, sampling-up four sub-soils at $0-30 \mathrm{~cm}$ at random from each of the waste dump sites to determine not only for heavy metal concentrations but also for fertility supplement in comparison with the National Environmental Standard and Regulation Enforcement Agency (NESREA). Also, fifty scheduled questionnaires were administered each on selected residents around dumped sites and to the staff of Town Planning Board to solicit for relevant information on government and its agencies effectiveness in disposal and management of waste. Landsat data was also used to map out the waste sites for spatio-temporal analysis from 1999 to 2016. Results are expected to inform major decisions makers and urban planners in order to promote a sustainable urban development for Sokoto metropolis and its environs.

Keywords: developing world, protection agencies, Metropolis, urban planners, Sokoto

\section{Introduction}

The production and clearance of waste is an essential part of any developing society like Nigeria. Waste, both from domestic and commercial sources has grown significantly in Nigeria over the past decade. Every time a householder shops at the store, and open market he contributes to the mountain of waste (Iwegbue et al. 2006). It is possible to quote figures which show that the production of waste amounts to millions of tons. The percent of Nigeria's population living in cities and urban areas has more than doubled in the last 15 years (Jimoh 2005). The cities and

\footnotetext{
*Reader, Department of Geography and Environmental Management, Faculty of Social Sciences, University of Ilorin, Nigeria.

${ }^{+} \mathrm{PhD}$ Student, Department of Geography, Faculty of Social Sciences, Usmanu Danfodiyo University, Nigeria.

${ }^{ \pm}$Lecturer 1, Department of Geography, Faculty of Social Sciences, Usmanu Danfodiyo University, Nigeria.

Researcher, Department of Geography, Faculty of Social Sciences, Usmanu Danfodiyo University, Nigeria.
} 
urban areas experience continuous growth which contributes to enormous in generation of solid and liquid waste. The management of waste is a matter of national and international concern. The volume of waste does not actually constitute the problem but the ability or inability of governments, individuals and waste disposal firms to keep up with the task of managing waste and the environment (Joseph et al. 2016). There is no doubt that a dirty environment affects the standard of living, aesthetic sensibilities, health of the people and thus the quality of their lives (Mowoe1990). Waste often generated by human beings since time immemorial has continued to be a threatening problem and a growing one that is of major concern to every nation of the world. In Nigeria today, among the pressing environmental and public health issues are the problems of solid waste generation, control and disposal. Although the problem of solid waste disposal is as old as man's existence that is inextricably linked to the generation of waste, the truth is that in many cities and urban centers, it has become so intractable that even the government is overwhelmed (Jimoh 2005, Momodu, et al. 2011).

Waste according to Douglas (2004) is any unwanted and discarded material that arises from the activities of humans and animals on earth. For Onwughara et al. (2010), urban solid waste (USW) covers a broad range of materials including garbage, refuse from factories, commercial refuse, construction and demolition debris, dead animals and abandoned vehicles, food particles, plastics, bottles, polythene material (nylon bag), metallic objects, furniture/wood material, paper and some other unclassified wastes. Rodgers (2011) submits that waste management is a systematic control of the generation, storage, collection, transportation, separation, processing, recovery and disposal of waste. Waste has been defined as something that is not or no longer useful and is to be thrown away or disposed of (Oxford Advanced Learner's Dictionary 1998). So also, waste has been defined as any material lacking direct value to the producer and so must be disposed of (Ita 2000). Among the European Community (EC), Waste Management Licensing Regulations 1999 came into force to implement the Framework Directive on Waste (Malcolm 1994, NESREA 2009). The Regulations also implement all of the remaining section of part II of the UK Environmental Protection Act, 1990, which defined waste as any substance which constitutes a scrap material or an effluent or other unwanted surplus substance from the application of any process (Atsegbua 2003). Generally waste poses a significantly different threat to human health in any environment, partly because of the manner in which it may be disposed or managed may not conform to proper standard. Waste therefore, is something which falls out of the normal commercial circle or utility. The European Commission (2020) suggests some broad category options which may be considered before or not an object is regarded as a waste: any worn out but still functioning substances or objects after repair is not a waste; objects which can be put to immediate use by a specialized waste recovery operation not to be considered as a waste; degenerated substances or objects which can be put to use only by establishments or undertaking specializing fall not to be regarded as wastes but any substance which the holder does not want and which he has to pay to be taken away are wastes, where the holder intends that the objects are to be discarded. 
The above are only suggestive and would actually be meaningless except to rating authorities or waste disposal agencies who are interested in their fees for collection and disposal of waste.

In Nigeria, The Federal Environmental Protection Agency (FEPA) established an Act in 1988 No. 58; 1992 No. 59 and 1999 No. 14 with their functions and the powers for the effective implementation of such functions (FEPA 1989). But these acts did not define waste. Only some state statutes attempted to do so making some of them have different Edict as to control wastes (see list below). For example, section 32 of the Lagos State Environmental Sanitation Edict11 has a definition similar to the UK Environmental Protection Act 1990 (1st October 2017) 12, refers to waste as follows:

a. Waste of all descriptions.

b. Any substance which constitutes a scrap material, an effluent or other unwanted surplus substance arising from the application of any process.

c. The UK Act 1990 Integrated Pollution Control and Air Pollution Control by Local Authorities.

\section{Institutions that Regulate Waste Control \& Management in Nigeria}

As part of proactive measures by Nigerian government to preserve the environment and protect its inhabitants from hazardous wastes and nuisance, as well to make it incumbent on all states of the federation to join in the crusade for hygienic standard in the country. Government and several states have established various governmental authorities and agencies that control and manage wastes in their respective areas. But it was discovered that only few States in the northern parts of the country are engaged in this practice. Therefore, the control and management of wastes is perilous and dwindle in Sokoto state in general. In Nigeria as a whole the following are the selected list of solid waste management stakeholders both at the Federal and States' levels (FEPA 1989).

- Federal Ministry of Environment (FMOE)

- Federal Environmental Protection Agency (FEPA)

- Lagos State Waste Disposal Board (LSWDB)

- Lagos State Environmental Protection Agency (LASEPA)

- Kano State Environmental Protection Agency

- Oyo State Environmental Protection Commission

- National Oil Spill Detection and Response Agency (NOSDRA)

- Federal Ministry of Environment, Housing and Urban Development (FMEHUD)

- Department of Petroleum Resources

- Kaduna State Environmental Protection Agency

- River State Environmental Protection Agency

- Anambra State Ministry of Environment, Mineral Resources, Science \& Technology, Akwa 
- Enugu State Environmental Protection Agency

- Abuja Environmental Protection Agency

- Adamawa State Ministry of Environment, Yola

- Away Ibom State Ministry of Environment \& Mineral Resources, Uyo

- Bauchi State Environmental Protection Agency, Bauchi

- Baileys State Environmental Sanitation Authority, Yenagoa

- Benue State Environmental Sanitation Authority (BENSESA), Makurdi

- Borno State Ministry of Environment, Maiduguri

- Cross River Ministry of Environment, Calabar.

- Delta State Waste Management Board, Asaba

- Ebonyi State Ministry of Health \& Environmental, Abakaliki,

- Edo State Environmental \& Waste Management Board, Benin City

- Ekiti State Waste Management Board, Ado Ekiti

- Enugu State Waste Management Authority, Enugu

- Gombe State Environmental Sanitation \& Protection Agency, Gombe

- Imo State Ministry of Petroleum \& Environment, Owerri

- Jigawa State Rural Water Supply \& Sanitation Agency, Dutse.

- Kaduna State Ministry of Environment \& Natural Resources, Kaduna

- Kaduna State Waste \& Sanitation Project, Kaduna

- Kano State Refuse Management \& Sanitation Board (REMASAB), Kano

- Kano State Rural Water Supply \& Sanitation Agency (RUWASA), Kano

- Katsina State Rural Water Supply \& Sanitation Agency, Katsina

- Kebbi State Ministry of Environment, BirninKebbi

- Kogi State Ministry of Environment \& Physical Planning Development, Lokoja

- Kwara State Environmental Protection Agency, Ilorin

- Niger State Environmental Protection Agency, Minna

- Ogun State Environmental Protection Agency, Abeokuta

- Ondo State Waste Management Authority, Akure

- Osun State Environmental Protection Agency, Osogbo

- Oyo State Ministry of Environment \& Water Resources, Ibadan

- Plateau State Environmental Protection \& Sanitation Agency, Jos

- River State Environmental Sanitation Authority, Port Harcourt

- Taraba State Environmental Protection Agency, Jalingo

- Yobe State Environmental Protection Agency, Damaturu

- Zamfara State Ministry of Environment \& Solid Minerals Development, Zamfara

- Waste Management Society of Nigeria, Akwa Ibom

There are lots of reports being carried out on waste management and control especially in developed world and in the developing nations. Some of these reports are released by the International Solid Waste Association (ISWA) and the United Nations Environment Programme. ISWA has a total of more than 1,200 members in 93 countries. Its network expands to countries with more than $80 \%$ of the 
world's population. ISWA has three membership categories: national members, organization members and individual members. At present, there are 32 national members or incoming national members that represent their country on solid waste issues. ISWA's national members represent countries with $48 \%$ of the world population and $87 \%$ in terms of global GNP. ISWA's members represent all aspects of our field and most regions worldwide: from practitioners and industry to communities, from associations, research institutes and academics to regulatory authorities. The association is the global forum for waste management, with 12 technical working groups covering all relevant aspects of sustainable waste management and with special interest in developing countries issues:

- Working Group on Biological Treatment of Wastes.

- Working Group on Economic Analyses for Sustainable Development.

- Working Group on Hazardous Wastes.

- Working Group on Healthcare Waste.

- Working Group on Legal Issues.

- Working Group on Recycling and Waste Minimizations.

- Working Group on Sanitary Landfill.

- Working Group on Sewage and Waterworks Sludge.

- Working Group on Thermal Treatment.

The scope of this report is limited to the management of Municipal Solid Waste (MSW) (Hoornweg et al. 2012). Environmentally sound management of solid wastes environmentally sound waste management is recognized by most countries as an issue of major concern. For both developing and developed countries, waste management is an important factor in ensuring both human health and environmental protection. Article 21.4 of Agenda 21 states that 'Environmentally sound waste management must go beyond the mere safe disposal or recovery of wastes that are generated and seek to address the root cause of the problem by attempting to change unsustainable patterns of production and consumption.' Sustainable waste management is realized by using the technical, organizational and financial resources available in a particular locality.

Internationally, the management of solid waste is a huge challenge for municipalities in developing nations. Previous studies point out that increase in population with relating concomitant urbanization dynamics and growth of conurbations will further exacerbate this challenge (Bogner et al. 2005). Monni et al. (2006) reported on five global scenarios compiled from 1990 to 2050 on global post-consumer waste generation. They stated global emissions from landfills in 1990 to be $340 \mathrm{Tg} \mathrm{CO}_{2}$ eq with an increase to $1,500 \mathrm{Tg} \mathrm{CO}_{2}$ eq by 2030 and to 2,900 Tg $\mathrm{CO}_{2}$ eq by 2050. Laurent et al. (2014) and Zhang et al. (2019) more recently reviewed greenhouse gas (GHG) emissions from landfills and listed a number of important mitigation methods as well as development and dissemination of updated knowledge-based frameworks. At present, the World Bank affirms 2.01 billion metric tons of municipal solid waste. MSW are produced annually worldwide, with estimates reaching 3.40 billion metric tons by 2050 (Sipra et al. 2018). Current worldwide estimates indicate that, $13.5 \%$ of waste is recycled and 
$5.5 \%$ is composted, with an estimated one-third and $40 \%$ of MSW as not managed properly and instead dumped or openly burned (Huang et al. 2006). This mismanagement is significantly split between developed and developing countries. For example, about $80 \%$ of solid waste in African countries is dumped indiscriminately in open spaces, streets, storm water drains, rivers, and streams (Afon and Okewole 2007), thereby, estimated to contribute to about 29\% of the global GHG emissions and expected to increase to $64 \%$ by 2030 . This is largely due to uncontrolled population growth and affluence, unsustainable development activities, and expansion of waste collection services without sufficient management strategies (i.e., changes from dumpsites to sanitary landfills with a lack of landfill gas collection). Dladla et al. (2016) identified factors associated with indiscriminate dumping of waste in eleven African countries (Nigeria inclusive) and found institutional weaknesses and lack of awareness as key starting points to the problem. Lack of public perception can be a limitation to what can be done and, ultimately, to what can be achieved (Yuan et al. 2019). African countries that are heavily inundated with indiscriminate MSW constitute health challenges to residents of the area as GHGs are released (Zhang et al. 2019). Institutional weaknesses may occur in the form of ambiguity of waste management policy and legislation since MSW activities effect the core infrastructural framework of a municipality and its residents. Hence, increasing awareness of inhabitants may have a positive impact on attitude as well as perception towards the environment.

Nigerian cities are largely characterized with having solid waste disposal problems. They are typified by overflowing dumpsters, mountains of open refuse dumps (i.e., on virtually every street), and makeshift landfills on the edge of larger suburbs and towns. Attendee problems are also evident, especially where burning occurs, since properly operated landfills are nonexistent and often rodent infested with surface and ground water pollution concerns (Cirella et al. 2019). As such, the collection and transport of MSW requires the largest demand on municipal budgets but has been seen to have the greatest impact on urban living (UNHABITAT, 2010). Oseghale (2011) and Ezeudu and Ezeudu (2019) reported that in Nigeria $68 \%$ of MSW is indiscriminately dumped, $20.8 \%$ is disposed through inappropriate landfill sites, and $10.7 \%$ is burnt. According to the GHG emissions inventory from 2000 to 2018 the contribution from inappropriate waste was $3.0 \%$ (FME 2018), which is expected to double within the next five years, considering that waste generation rate is estimated between 0.5 and $1.0 \mathrm{~kg} /$ person/day Oseghale (2011); however, this is subject to change due to unplanned population growth and unsustainable urban waste management practices Nigeria. Moreover, Ossai (2020) illustrated the complexity of waste composition Nigeria, stating biodegradable waste accounts for about $50 \%$ of annual MSW with less than $10 \%$ of waste as manageable.

Federal Ministry of Environment (FME) (2018), says Benin City, the largest urban center in Edo State, in southern Nigeria houses much of the challenges, thus far, described. Many of its suburbs (residential areas and public places) are littered with domestic and sewage waste, garbage, and chemical waste. Industrial operation is characterized by the generation of large volume of MSW in the form of solid, liquid and gas — some toxic. As a result, the Edo State Waste Management Board 
(EWMB), established by the local authorities, put in place a monitoring program to regulate environmental quality and implement steps towards a waste-free society. Despite its efforts, Benin City still falls short of achieving Board benchmark levels and ongoing waste management practices are needed. This paper examines an indepth look at the level of awareness and attitude of its inhabitants towards MSW disposal and possible contribution to regional GHG emissions. The research is in accordance with the local government, with the intention of enhancing MSW management programs for other Nigerian cities and beyond which face similar problems.

\section{Methods}

The methods employed for this work are highlighted below: In the first place, reconnaissance visits were carried out by the researchers on different occasions at different locations within Sokoto metropolis for On-the-spot assessment and for Focus Group Discussion (FGD). This was done in as to discover the locations of dumpsites (Legal or Illegal sites) and to update information collected from the secondary data source. Mapping of major waste sites in the metropolitan areas were also put in place based on snowball sampling method. The outline coordinates of the waste sites were taken by walking around the boundaries of the waste dump sites with the aid of a hand-held Global Positioning System (GPS). Map of Nigeria states and capitals were displayed to show list of solid waste management /stakeholders in the Federal and States with their respective locations (see Figure 1). Sites were also observed and photographed to see some category of wastes composition and waste characteristics based on soil sampled from the waste sites respectively (see Figure 3). The results of the outcome were discussed in details within next paragraphs.

\section{Figure 1. Nigeria States \& Capital Cities}

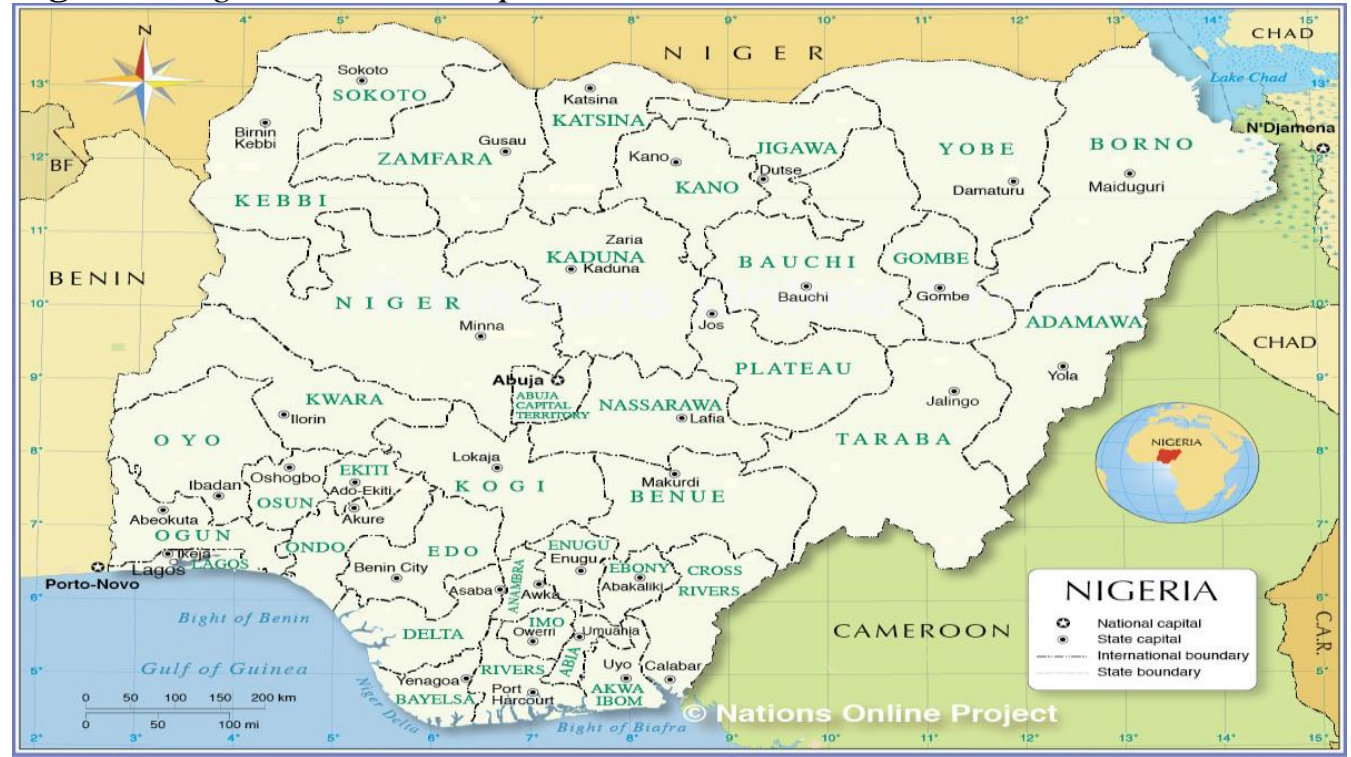

Source: ontheworldmap.com. 
Figure 2. Few Waste Sites in Sokoto Metropolis

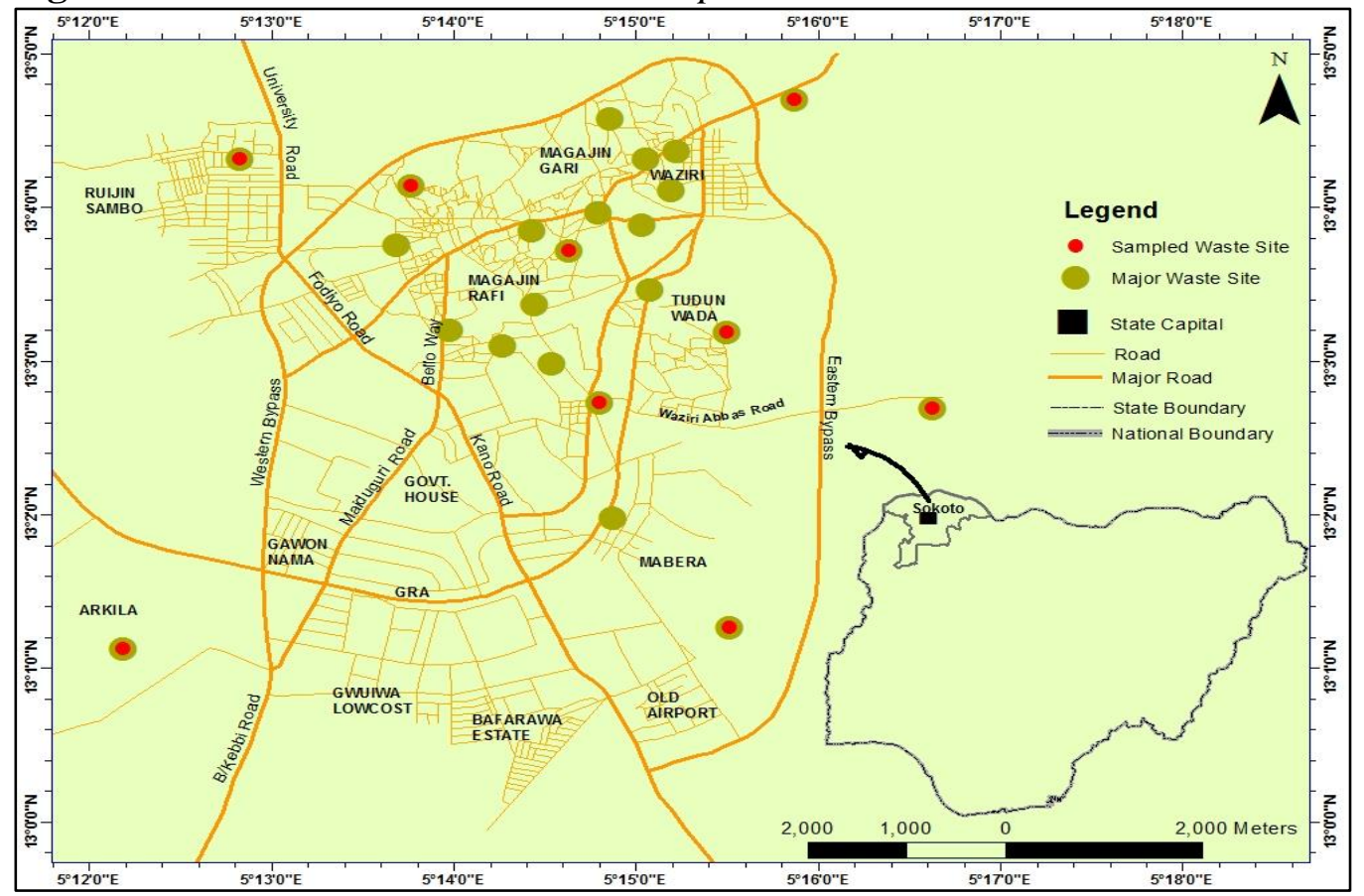

Source: Authors' Compilation.

\section{Soil Sampling and Composition of Waste Materials in Sites}

The material compositions of wastes in Sokoto metropolis were determined through soil samples that were collected from the sites by the use of Soil Auger from $0-15 \mathrm{~cm}$ depth. Samples were collected from each site in four replicates which were bulked, out of which a portion was taken in a clean polythene bag for laboratory test. Samples were provided as thus:

\section{Sample Digestion for Heavy Metals}

The soil samples were air dried for 72 hours, grounded and sieved with $2 \mathrm{~mm}$ mesh from which the representative sample was obtained. One gram of the air dried soil was taken from each sample and placed in a $100 \mathrm{~cm}^{3} \mathrm{Kjeldahl} \mathrm{digestion} \mathrm{flask}$ and treated with $2 \mathrm{~cm}^{3}$ of $60 \%$ chloric $(\mathrm{V})$ acid $\left(\mathrm{HClO}_{4}\right), 10 \mathrm{~cm}^{3}$ of concentrated nitric acid $\left(\mathrm{HNO}_{3}\right)$ and $1.0 \mathrm{~cm}^{3}$ concentrated sulphuric acids $\left(\mathrm{H}_{2} \mathrm{SO}_{4}\right)$. The mixtures were swirled gently and slowly at a moderate heat on the digester for 15 minutes and allowed to cool down, and later diluted with $50 \mathrm{~cm}^{3}$ of distilled water. The mixture was filtered through a filter paper into a $100 \mathrm{~cm}^{3}$ volumetric flask and used for test using the Atomic Absorption Spectrophotometer (AAS) (Akoto et al. 2016, Tijani et al. 2007). The results of the tests remitted the followings: It was discovered that soils of the waste dump sites were enriched with the heavy metals ( $\mathrm{Zn}, \mathrm{Cu}$ and $\mathrm{Cd}$ ) more than the adjacent soils (control) but were still within critical levels. 


\section{Heavy Metal Analysis}

The mean concentration for each heavy metal for all the sites was also tested with one-sample t-test against the NESREA standard to know whether it is safe for agricultural use or not.

\section{Major Waste Sites Commonly Found in Sokoto Metropolis}

Waste sites are usually found in the streets of the residential areas, behind walls of school buildings and places officially designated as dump sites provided with incinerators.

\section{Material Composition of Waste Sites}

Materials found are essentially household wastes such as polythene bag, paper, remnants of food, human and animal feces, metals and bottles, wood and plant remains.

\section{Heavy Metals in Soils at the Waste Site}

The heavy metals tested include zinc, lead, manganese, chromium and cadmium. The concentrations of the metals are presented in tables (see Tables 1 and 2). Also, Table 2 presents the critical values of the heavy metals by National Environmental Standards and Regulations Enforcement Agency (NESREA 2009, Bahaa-Eldin et al. 2008).

Table 1. Soil Heavy Metal Concentrations at Waste Sites

\begin{tabular}{|l|c|c|c|c|c|}
\hline \multirow{2}{*}{$\begin{array}{l}\text { S/ } \\
\text { No. }\end{array}$} & $\begin{array}{c}\text { Waste Sites in } \\
\text { Sokoto Metropolis }\end{array}$ & $\mathbf{Z n}$ & $\mathbf{P b}$ & $\mathbf{C r}$ & $\mathbf{C d}$ \\
\hline 1 & Ruijin Sambo & 0.594 & 0.397 & 0.076 & 0.016 \\
\hline 2 & MagajiGari & 0.174 & 0.513 & 0.112 & 0.007 \\
\hline 3 & Waziri area & 0.101 & 0.533 & 0.235 & 0.007 \\
\hline 4 & Magaji Rafi area & 0.242 & 0.383 & 0.183 & 0.010 \\
\hline 5 & Tudun Wada & 0.493 & 0.344 & 0.131 & 0.017 \\
\hline 6 & Waziri Abbas area & 0.691 & 0.221 & 0.221 & 0.023 \\
\hline 7 & Eastern bye-pass & 0.348 & 0.524 & 0.168 & 0.026 \\
\hline 8 & Mabera area & 0.890 & 0.442 & 0.217 & 0.008 \\
\hline 9 & Arkila & 0.131 & 0.338 & 0.141 & 0.011 \\
\hline \multicolumn{7}{|l}{ Mean Total } & $0.407 \pm 0.28$ & $0.411 \pm 0.10$ & $0.165 \pm 0.05$ & $0.014 \pm 0.001$ \\
\hline
\end{tabular}

Source: Authors' Compilation. 
Table 2.Critical Limits for Heavy Metals in Soils

\begin{tabular}{|l|c|c|c|c|}
\hline Metals & Zn & Pb & Cr & Cd \\
\hline Critical Limit & 421 & 164 & 100 & 3 \\
\hline
\end{tabular}

Source: NESREA 2009.

\section{Challenges of Waste Disposal in Sokoto Metropolis}

In Sokoto metropolis, just as in some urban centers and cities in Nigeria, recycling activities are not popular and are almost none existence. But, the recovery of items from wastes (scavenging) is being practiced on a large scale. This type of recovery takes place at both legal and illegal dump sites where scavengers search continually for valuable items like; metals, plastics, and bottles to be reused or for sale to buyers of different type as scraps (Ahmed et al. 2017, Oyedele et al. 2008). In general, treatment of solid wastes is not often carried out in Nigeria. Incineration of wastes or use of approved sanitary landfill is non-existent. The most common practice is open dumping and burning of waste within residential areas and at illegal and legal dumps are very common in some major urban centers like; Sokoto and other places in the northern parts of Nigeria. Other strategies employed in disposing waste in the country include; collection, composting, transfer and bury all which are not modern means of waste management.

Most of the above are crude measures of wastes management and control and they are improper disposal or storage of waste that constitute hazards to the society through the pollution of air, land and water. Thus, waste management has become a common issue of discourse among individuals, groups and governments and there is the need for its overhaul development to meet the modern world standard (Partha et al. 2011).

\section{Roles Play SEPA on Waste Management in Sokoto}

The major roles of the Sokoto Environmental Protection Agency (SEPA) are to keep the metropolis clean, collect and evacuate household solid wastes at designated points in the metropolis and enforce compliance with sanitary rules and regulations. SEPA is the only authorized body vested with waste management responsibility, although scavengers usually engage themselves at the waste sites collecting metal parts, plastic materials and other items that can be industrially reused or recycled. However, the wanton littering of the streets with heaps of wastes is an illustration of the fact that the Agency is overwhelmed. The process of keeping the metropolis clean involves a general sanitation exercise observed for three hours once in a month, and this takes place on the last Saturday of the month. The exercise is expected to involve every able inhabitant of the metropolis cleaning his or her environment between 7am and 10am within when vehicular movements are not allowed. However, this practice has remained a mere observance as movements only get restricted with little participation by the city residents. Surroundings are supposed to be swept while wastes derived from the activity are expected to be 
deposited at designated receptacles and areas from where they are collected by the SEPA.

Wastes are either dumped at open spaces indiscriminately at points designated by inhabitants of an area or into receptacles provided by the Agency, the capacities of which are fast exceeded largely due to the high volumes of generated waste. The receptacles are either metallic containers or refuse bunkers located at strategic places. Nonetheless, residents fail to access the points, thereby dumping piles of rubbish which normally litter the roads and street corners of the metropolis. This situation is worse in densely populated areas of Sokoto city center such as; Sarkin Zamfara B ward, Sarkin Zamfara ward A, Rijia ward A, Rijiya ward B and Sudan Wada Ward A and B respectively (in Sokoto South LGA). It is also very visible in areas like Magajin-Garin ward A and B and Waziri Ward A and B respectively (in Sokoto LGA) of Sokoto metropolis as evident in Figures 3-10.

\section{Characteristics of Wastes Generated by Households in Sokoto City}

The types of solid waste generated by households in the metropolis are biodegradable and non-biodegradable. The biodegradable waste include vegetables, food remnants, paper, cartons, textile materials, animal carcass, leaves, grasses, and wood products which constitute approximately $98 \%$ of the total waste being generated. While, a negligible amount of non-biodegradable waste includes; bottles, glass, polythene bags, plastic materials and scrap metals are generated, evacuated and disposed daily. An approximate amount of solid waste generated, evacuated and disposed daily is about $750,000 \mathrm{~kg}$ (750tons), weekly $5,250,000 \mathrm{~kg}$ (5,250tons), monthly $21,000,000 \mathrm{~kg}$ (21,000tons) and yearly at about $252,000,000 \mathrm{~kg}(252,000 \mathrm{tons})$. The waste materials collected by SEPA have either spilled to the ground from the receptacles due to overuse or are intentionally dumped on the ground in massive proportions by the residents. In collecting solid wastes at such sites, heavy equipment such as bulldozers, pay loaders, tractors, trucks and tippers, wheelbarrows, shovels, forks, among others are used. Waste transportation is carried out by high capacity tippers so that they can convey high volumes over long distances to the treatment sites. These wastes conveyed by the carriers (Figure 8) are routinely contained with tarpaulin so they do not get blown out of the vehicle in transit, thereby becoming stranded and dirtying the roads; also, the wastes are contained to prevent escape of noisome odors from the waste.

Figure 3. Waste Dump Site at Maituta Road

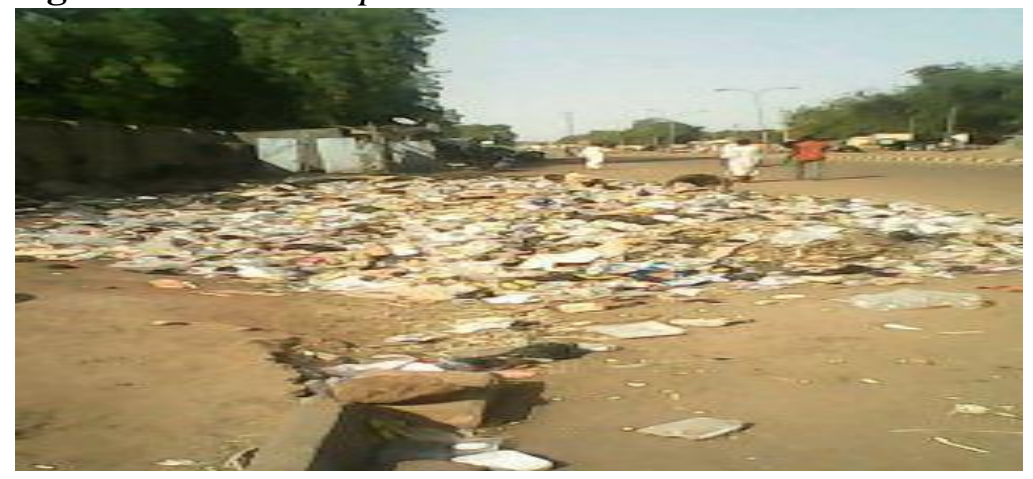


Figure 4. Waste Dump Site at Sarkin-Zamfara ward 'A'

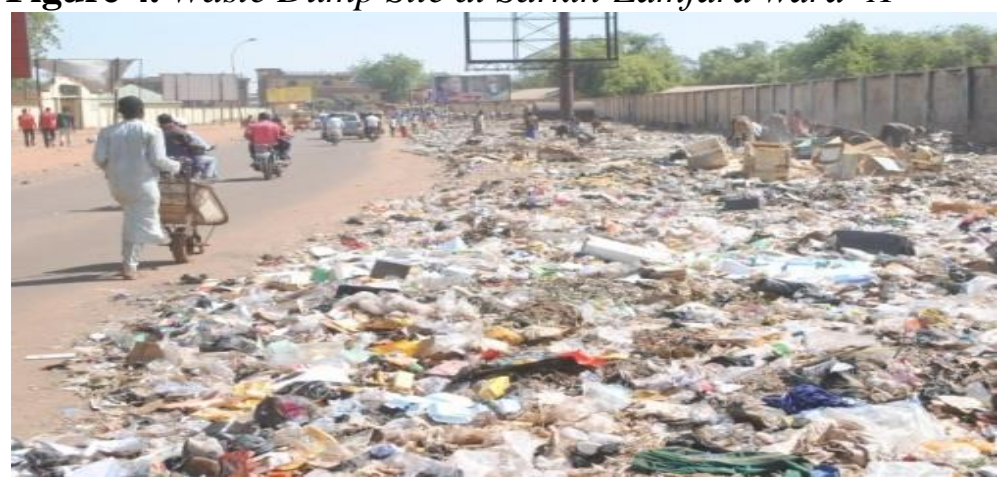

Figure 5. Waste Dump-site at Sarkin ZamfaraWard ' $B$ '

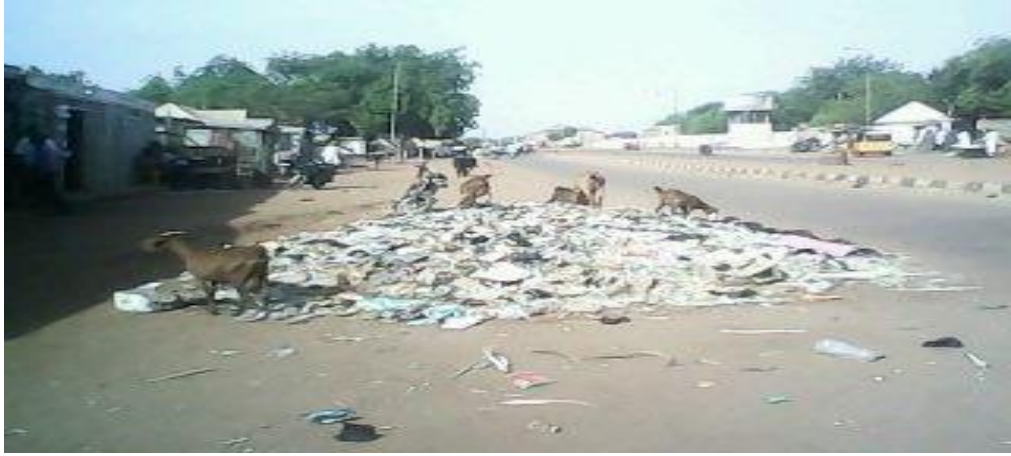

Figure 6. Waste Dump Site at Rijia-Ward 'A'

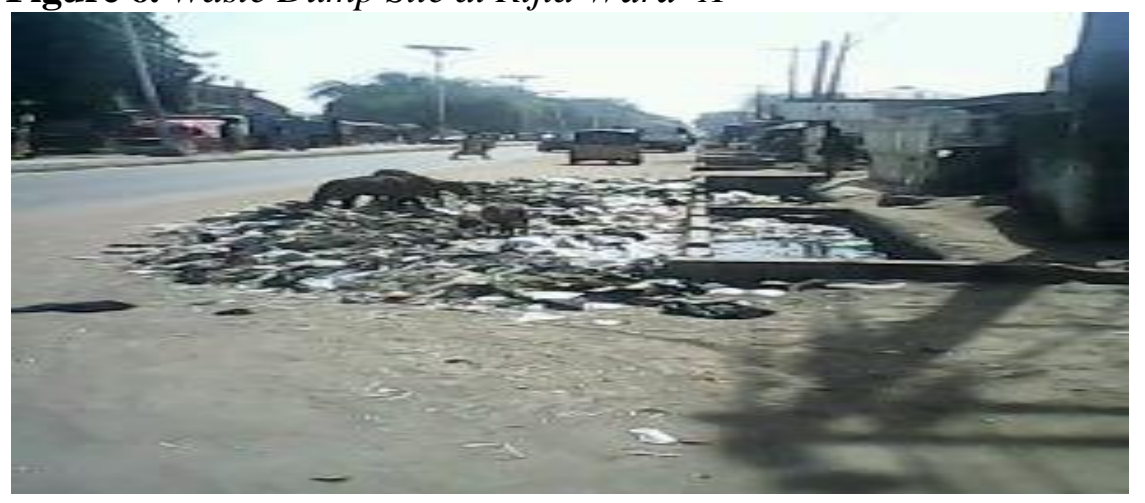

Figure 7. Waste Dump Site at TudunWada Area

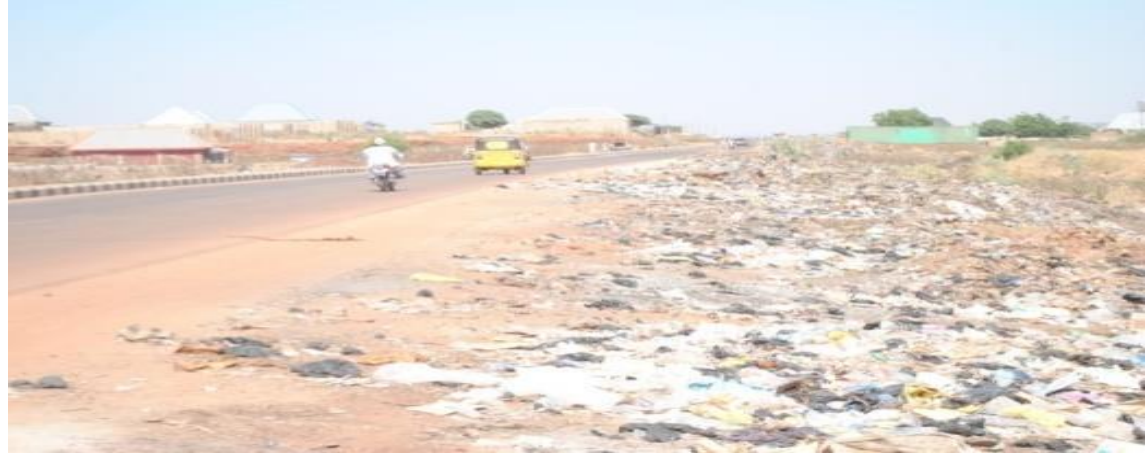


Figure 8. Equipment for Evacuating Solid Waste

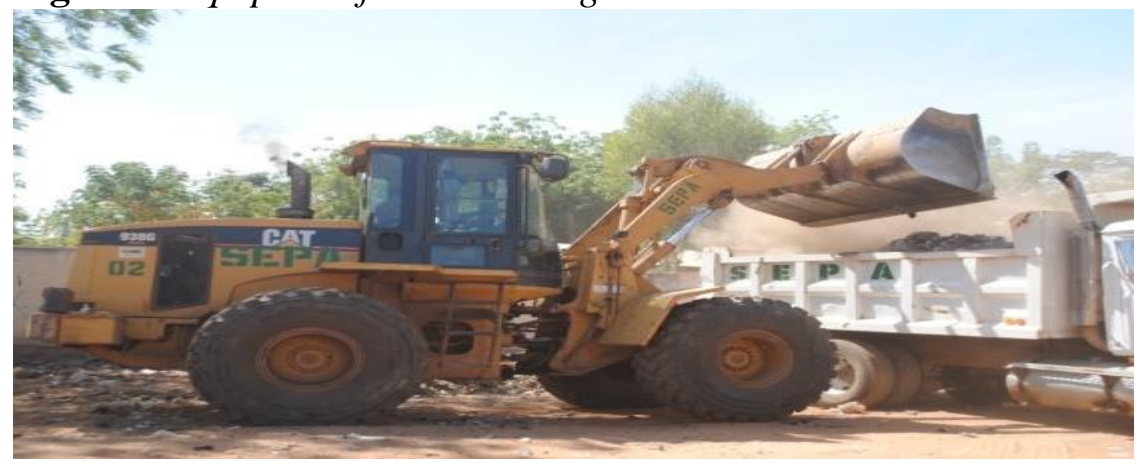

Figure 9. SEPA's Metal Skip for Safe Refuse

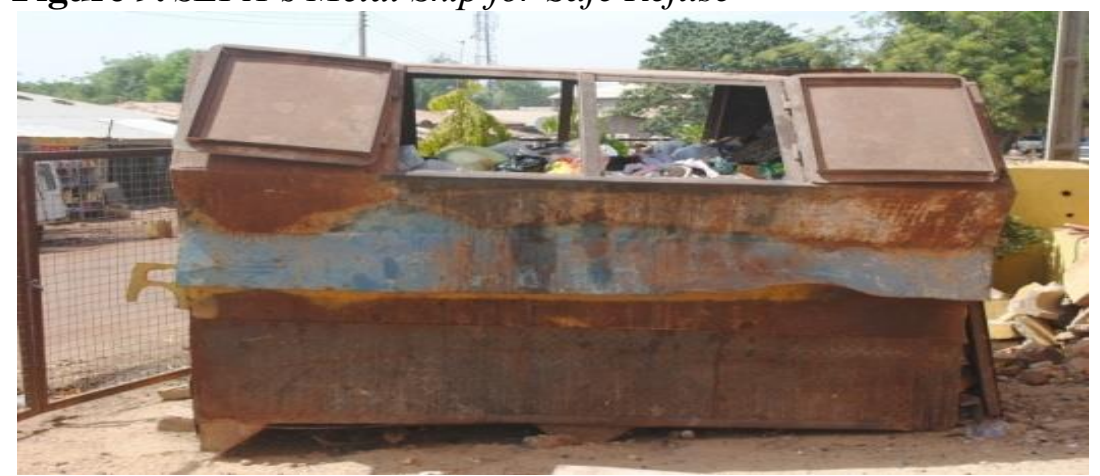

Figure 10. Opened Waste Dump Site Disposal at Waziri Ward 'A'

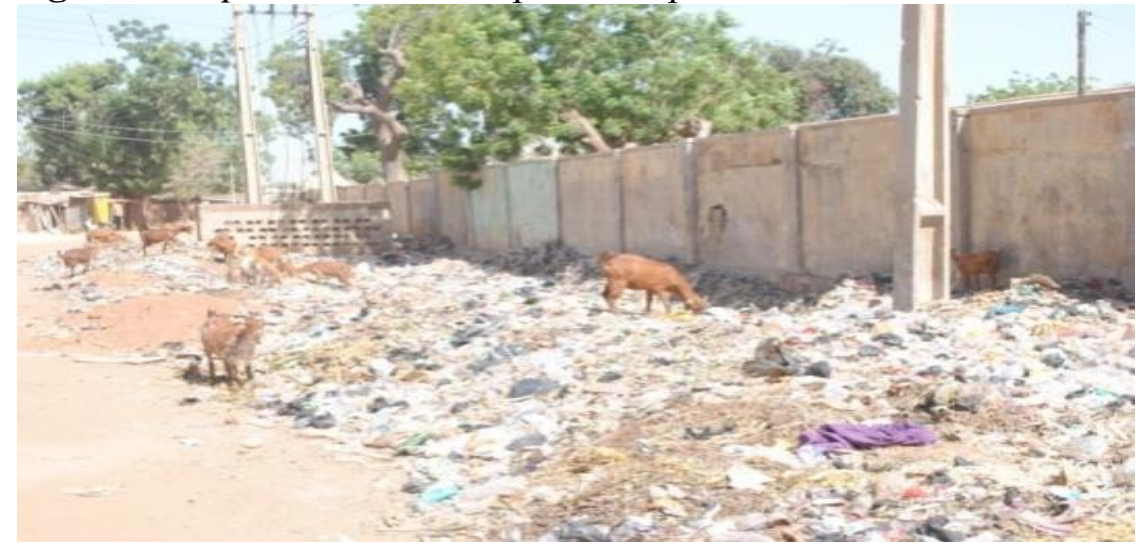

\section{Results and Discussion}

On the general feeling of respondents on the cleanliness of the metropolis, $89 \%$ of them agreed that Sokoto metropolis is dirty. They argued that the metropolis is characterized by heaps of household solid wastes which are left stranded for long periods of time before evacuated. As some of the generated wastes are biodegradable, most streets especially in the congested areas remain air polluted, mosquito infested and littered with nylons of different types. 
On the mechanism used by households to control solid waste in the metropolis, most respondents claimed SEPA provided refuse bunkers and metal skip that are distributed at strategic locations within the metropolis, but are grossly inadequate and located at far distances from most residents. This however has made the residents of the metropolis to adopt the method of designating an open space as household solid waste dump site. Other residents have equally cultivated the habit of dumping their waste in nearby bushes and uncompleted buildings or open plots of land, and in front of drainage along major streets. Some residents indiscriminately dump waste in front of their houses while some rich individuals among them organized for the services of private firms or local scavengers who go about with wheel barrows to collect household solid wastes from homes on payment services. These groups of refuse collectors are mostly found every morning in densely populated areas of the metropolis and commercial areas of Emir Yahaya Road, Rijiya Area, Old Airport Area, Ahmadu Bello way, Zoo lane area, Jallen Area and Fodio Road Area respectively to render their services. This practice of indiscriminate refuse dumping has led to the situation in which improperly sited open dumps deface several parts of the major roads, streets, street corners and high ways in the metropolis with exposed and fermenting refuse with repugnant, offensive and nuisance odors almost everywhere in the metropolis.

On the frequency of waste evacuation by SEPA, $74 \%$ of the respondents argued that wastes at their area are evacuated about once a month, while $26 \%$ could not be specific but maintained that the frequency is low. In terms of the mechanism of waste management, $56 \%$ of the respondents argued that best and standard practices have not been adopted by SEPA. According to them, the use of heavy duty trucks and earth moving machineries that driven and operated for many hours in the densely populated environment cause noise and air pollution which is detrimental to human health. This is besides the traffic impendence that comes with the operations of these heavy duty machineries. About $90 \%$ of the respondents also argued that SEPA transports waste materials without covering the loaded trucks with tarpaulin, thereby making the materials in transit to fly and drop on the roads. Thus, such materials find their ways into the drainage channels to cause further problem.

Other salient reasons in which mechanism adopted for household solid waste collection and disposal could not be said to be one of the best standard practice could be traced to the unplanned houses, narrow and none paved winding roads, streets and degraded environment which prevent timely evacuation of piles of rubbish littering the roads and street corners. Respondents further argued that lack of adherence to city planning is a fundamental reason for inaccessibility. It could also hamper the free movement of appropriate refuse collection and disposal equipment such as compactor trucks.

In the case of waste control and management in Sokoto through heavy metal concentrations studies, this was found to be below the critical limits set by the NESREA. The waste materials that generate them are essentially domestic. This gives a room for a guess that perhaps domestic wastes are fewer sources of heavy metals than industrial wastes which is partly why low values were observed in this study. It is also safe to infer that sandy soil which largely characterizes the study 
area is partly responsible for the observed concentrations as leaching that occurs mostly in sandy soils around the metropolis.

Upon all the government efforts to alleviate poor waste management and control in Sokoto metropolis, a number of challenges still continued to crop up as a result of the following.

- Dwindle of moral ethics towards environment enlighten on which most people are yet to learn or comply due to their indifferent attitudes towards environmental management and control.

- Increasing migrant traders into the city from all over neighboring states and countries that continuing to increasing the quantity of waste generated, thus making it more difficult to make adequate provision to commensurate with wastes generated.

- Distribution of heavy metals [lead $(\mathrm{Pb})$, copper $(\mathrm{Cu})$ and zinc $(\mathrm{Zn})$ ] is relevant in surface soil study (e-waste) and, recycling. The evaluationof pollution size (spot size, small area or larger), as well as assess to heavy metal transport into the surrounding soil environment have its challenges in Sahellian region like Sokoto (Fujimori and Takigami 2014).

- No enough manpower to manage wastes as there are just few sanitation and environment engineers in the state. Whereas, most private sector operators in waste management are mainly political stalwarts and who have little knowledge about waste control and management.

- Weak enforcement agency mostly in developing countries also makes people to be careless with waste management policies.

- Lack of modern technology/lethargy.

- Poor funding by Waste Management Agency i.e., in places where people pay to dispose waste makes it a challenge for the financially less privileged to comply with such policies (Ahmed et al.2017).

This study which assessed urban solid waste management in Sokoto state with its attention focused on city of Sokoto specifically, the work sought to find out why indiscriminate solid waste dumps/disposal have persisted in the city. We intend to investigate the measures to put in order to curtail the tide and ascertain the extent to which indiscriminate waste disposal affects people's health and environment and other ways of life. Evacuated wastes are dumped at the designated treatment points only in the outlying parts of the metropolis. While dumping distance not enough to prevent pollution to the city. Some dumping of refuse is done in the open spaces while others are at any available pits. Because Sokoto metropolis experiences high and frequent winds and since the capacity to industrially recycle wastes is lacking, the wastes are incinerated to prevent them from getting transported back to their origins by winds. Incineration is also carried out to prevent mosquito breeding at the treatment sites. On the challenges faced by the SEPA, many residents of the city cited paucity of funds, inadequacy of equipment, inaccessibility of some streets especially the congested and unplanned areas and non-compliance of the residents to sanitary rules and regulations as the main problems bedeviling the Agency's operations. According to them, funds are grossly inadequate to purchase the 
necessary equipment like row-row, waste bins, towing vehicles, waste pulverization machines among other modern gadgets for daily use by waste managers.

\section{Conclusions}

The findings of this study leave nobody in doubt about the devastating effects of urban solid waste in Sokoto metropolis as a result of inapt and dwindling waste management. We therefore put forward that both the individuals and the government through SEPA have some decisive roles to play in synthesis residents of metropolis on efforts to educate them about health living standard by all and sundry. As the resultant negative consequences will have multiplier effects on the present and future inhabitants of the metropolis. Government is therefore advised to re-orientate the masses through enlightenment campaigns about best ways to dispose solid wastes with the seriousness they deserve if they must keep faith with protecting the environment and lives of people in Sokoto states in general. The study avers that SEPA's waste control efforts are grossly inadequate, besides their collecting bins spots locations that are too far from one and another, and/or partly the residents manage their waste products by indiscriminate dumping on different illegal avenues by households. All these measures must be discouraged, while SEPA is encouraged from all measures that hampering their progress such as poor funding, inadequate machinery and unplanned nature of most parts of the metropolis which imposes considerable limitations on waste evacuation, deposition and outright total disposal.

\section{Recommendations}

In line with the findings from this study and its implications, the following predictable mitigation features are put forward on the syndrome to serve as futuristic solutions to the waste management challenges in Sokoto metropolis.

i. Sokoto State in general, should as a matter of urgency strengthen the already established SEPA to manage and preserve the environment, and protect its inhabitants from hazardous waste problems by making it incumbent on all Local Government Areas in the state, to join hands in the crusade for hygienic standard in their areas.

ii. The State Government could not shoulder all the brunt of waste control and management, but government should establish partner with firms under public-private-partnership (PPP) arrangement to commence operation in the state as co-specialists in waste management operation that would include: waste generation, sorting/separation, recycling and conversion as it is being done in some modern cities of the world (Bahaa-Eldin et al.2008).

iii. State government should as a matter of urgency; provide permanent waste dumpsites that must be far away from health service centers, 
markets, schools, churches, commercial and residential areas. This will curtail the risk of infectious diseases catch and spread within the city environment.

iv. Landlords/head of households and other residents within the metropolis should be appropriately represented and well informed when planning for any new waste control management strategy.

v. Institutions like; Primary and secondary school should incorporate in their curricula relevant and important topics on waste control, this would make all students have knowledge of waste management from grassroots.

vi. The various media organizations including radio, television, magazines, and newspapers and so on should complement government's efforts to sensitize the residents on the dangers of dirty environment and the need to maintain good personal and environmental hygiene.

vii. All the above suggestions could work if followed with regular public enlightenments, symposia, workshops and seminars to sensitize residents on the modalities for waste control from point of generation to collection and disposal centers which must be increased beyond the current limited SEPA equipment.

viii. Employment of more skilled officers in environmental pollution control and waste management into SEPA would be another added advantage, they could as well work together with other health management bodies in the State in order to jointly uplift health condition of all the populace in Sokoto State and Nigeria in general.

\section{References}

Ahmed YA, Muhammed AA, Oyewo SO (2017) Health impact of leachates from illegal dumpsites: case study of Kubwa Abuja, Nigeria. Ethiopian Journal of Environmental Studies and Management 10(1): 125-136.

Afon AO, Okewole A (2007) Estimating the quantity of solid waste generation in Oyo, Nigeria. Waste Management \& Research: The Journal for a Sustainable Circular Economy 25(4): 371-379.

Akoto O, Nimako C, Asante BD (2016) Heavy metals enrichment in surface soil from abandoned waste disposal sites in a hot and wet tropical area. Environmental Processes 3(Aug): 747-761.

Atsegbua LA (2003) Environmental law in Nigeria: theory and practice. Lagos, Nigeria Ababa Press.

Bahaa-Eldin EAR, Yusoff I, Rahim SA, Zuhairi WYW, Ghani MRA (2008) Heavy metal contamination of soil beneath a waste disposal site at Dengkil, Selangor, and Malaysia. Soil and Sediment Contamination 17(5): 449-466.

Bogner J, Spokas K, Chanton J, Powelson D, Abichou T (2005) Modeling landfill methane emissions from biocovers: a combined theoretical-empirical approach. In Proceedings of the Sardinia 2005 International Solid and Hazardous Waste Symposium (CISA). University of Cagliari.

Cirella GT, Iyalomhe FO, Adekola PO (2019) Determinants of flooding and strategies for mitigation: two-year case study of Benin City. Geosciences 9(3): 136. 
Dladla I, Machete F, Shale K (2016) A review of factors associated with indiscriminate dumping of waste in eleven African countries. African Journal of Science Technology Innovation and Development 8(5-6): 475-481.

Douglas SE (2004) The politics of Nigeria underdevelopment. Journal of Policy and Development Studies 1(2) 34-39.

European Commission (2020) Circular economy in cities. European Commission.

Ezeudu OB, Ezeudu TS (2019) Implementation of circular economy principles in industrial solid waste management: case studies from a developing economy (Nigeria). Recycling 4(4): 42.

Federal Environmental Protection Agency - FEPA (1989) National policy on the environment. Federal Republic of Nigeria.

Federal Ministry of Environment - FME (2018) First biennial update report under the united nations framework convention on climate change. Abuja: Federal Ministry of Environment.

Fujimori T, Takigami H (2014) Pollution distribution of heavy metals in surface soil at an informal electronic-waste recycling site. Environmental Geochemistry and Health 36(1): 159-168.

Hoornweg D, Bhada-Tata P (2012) What a waste: a global review of solid waste management. Urban Development Series; Knowledge Papers No. 15. Washington: World Bank.

Huang Q, Wang Q, Dong L, Xi B, Zhou B (2006) The current situation of solid waste management in China. Journal of Materials Cycles and Waste Management 8(1): 6369.

Ita M (2000) Waste - Is the developing world ready. Science in Africa.

Iwegbue CMA, Isirimah NO, Igwe C, McWilliams ES (2006) Characteristic levels of heavy metals in soil profiles of automobile mechanic waste dumps in Nigeria. The Environmentalist 26(2): 123-128.

Jimoh IA (2005) A new approach to municipal waste management in Nigeria. In International Conference on Energy, Environment and Disasters-INCEED. USA: Charlotte N.C.

Joseph ON, Chinyere N, Chidi I (2016) Urban solid waste management and environmental sustainability in Abakaliki Urban, Nigeria. European Scientific Journal 12(23): 153185.

Laurent A, Clavreul J, Bernstad A, Bakas I, Niero M, Gentil E (2014) Methodological guidance for a better practice. Waste Management 34 (3): 589-606.

Malcolm RA (1994) Guide to environmental law, EC directive 91/156. London: Sweet \& Maxwell.

Momodu NS, Dimuna KO, Dimuna JE (2011) Mitigating the impacts of solid wastes in urban centers in Nigeria. Journal of Human Ecology 34(2): 125-133.

Monni S, Pipatti R, Lehtila A, Savolainen I, Syri S (2006) Global climate change mitigation scenarios for solid waste management. Espoo: VTT Technical Research Centre of Finland.

Mowoe KM (1990) Quality of life and environmental pollution and protection. In JA Omotola (ed.), Environmental Law in Nigeria. Lagos, Nigeria: Faculty of Law, University of Lagos.

National Environmental Standards and Regulations Enforcement Agency - NESREA (2009) National environmental (sanitation and wastes control) regulations. NESREA.

Onwughara IN, Nnorom IC, Kanno OC (2010) Issues in roadside disposal habit of municipal solid waste environmental impacts and implementation of sound management practices in developing country "Nigeria". International Journal of Environmental Science and Development 1(5): 23-31. 
Oseghale P (2011) Waste management handling in Benin City. Helsinki: Arcada University of Applied Sciences.

Ossai OS (2020) Comparative evaluation of qualitative and quantitative biogas production potential of oil palm fronds and co-digestion with cow dung. Journal of Energy Technologies and Policy 3(4): 25-33.

Oxford Advanced Learner's Dictionary (1998) Special price edition. England: Oxford University Press.

Oyedele DJ, Gasu MB, Awotoye OO (2008) Changes in soil properties and plant uptake of heavy metals on selected municipal solid waste dump sites in Ile-Ife, Nigeria. African Journal of Environmental Science and Technology 3(5): 107-115.

Partha V, Murthy NN, Saxena PR (2011) Assessment of heavy metal contamination in soil around hazardous waste disposal sites in Hyderabad city (India): natural and anthropogenic implications. Journal of Environmental Research and Management 2(2): 27-34.

Rodgers M (2011) Fundamentals of development administration. London: S. Publishers.

Sipra AT, Gao N, Sarwar H (2018) Municipal solid waste (MSW) pyrolysis for biofuel production: a review of effects of MSW components and catalysts. Fuel Processing Technology 175(Jun) 131-147.

Tijani MN, Okunlola OA, Ikpe EU (2007) A geochemical assessment of water and bottom sediments contamination of Eleyiele Lake Catchment, Ibadan, Southwestern Nigeria. Journal of Mining and Geology 19(1): 105-120.

UK Environmental Protection Act 1990 (2017, October 1) Waste definition for community. UK: Environmental Protection Agency.

UN-HABITAT (2010) Solid waste management in the world's cities: water and sanitation in the world's cities. London: Earthscan.

Yuan X, Fan X, Liang J, Mengyue L (2019) Public perception towards waste-to-energy as a waste management strategy: a case from Shandong, China. International Journal of Environmental Research and Public Health 16(16): 2997.

Zhang C, Xu T, Feng H, Chen S (2019) Greenhouse gas emissions from landfills: a review and bibliometric analysis. Sustainability 11(8): 2282. 
